\title{
Long-term biochemical changes in the islets of Langerhans in mice following infection with encephalomyocarditis virus
}

\author{
L. N. B. Hellqvist*, C. J. Rhodes and K. W. Taylor \\ Department of Biochemistry, The London Hospital Medical College, London, UK
}

\begin{abstract}
Summary. A mild diabetes was induced in mice following the inoculation of a myocardial variant of encephalomyocarditis virus. The majority of infected mice developed a transient hyperglycaemia and only a few mice exhibited a chronic elevation of blood glucose. Infected mice were selected for study if their non-fasting blood glucose levels were above two standard deviations of values in control mice for at least 5 consecutive days. The pancreas from selected inoculated mice and control mice was removed 60 days after infection; random blood glucose levels at this time had returned to normal. Isolated islets of Langerhans from such previously 'diabetic' mice were used to determine the rate of insulin secretion, insulin biosynthesis and cyclic AMP accumulation in response to various glucose concentrations. At glucose $(16 \mathrm{mmol} / 1)$, both insulin release and biosynthesis were depressed in previously infected animals. At glucose ( 2 and $10 \mathrm{mmol} / \mathrm{l})$, while insulin biosynthesis was unchanged in infected animals, insulin re-
\end{abstract}

lease was increased. Cyclic AMP accumulation in response to glucose $(20 \mathrm{mmol} / \mathrm{l})$ was found to be significantly elevated in islets from infected animals and especially in response to glucose $(20 \mathrm{mmol} / \mathrm{l})$ in the presence of isobutyl methyl xanthine $(1 \mathrm{mmol} / \mathrm{l})$. Infected mice exhibited a reduction of total pancreatic insulin content in comparison with control mice. The insulin content of isolated islets of Langerhans from infected and control mice was found to be the same. Serum insulin levels, however, from infected mice were higher than in control sera. The results suggest that the myocardial variant of encephalomyocarditis virus in certain inbred strains of mice causes alteration in some of the biochemical functions of the $\mathrm{B}$ cells, 60 days after infection. It is not known, however, how permanent these alterations are.

Key words: Diabetes, encephalomyocarditis virus, islets of Langerhans, cyclic AMP, immunoreactive insulin.
A diabetes mellitus-like syndrome develops in certain inbred strains of mice following infection with the myocardial variant of encephalomyocarditis virus (EMC-M virus) $[1,2]$. Coxsackie B4 virus is another picornavirus able to induce a diabetes-like syndrome in mice $[3,4]$. More recently, Toniolo et al. [5] showed that all six members of the Coxsackie B4 virus groups are able to induce varying degrees of glucose intolerance in mice. These viruses may rapidly destroy the cells in which they replicate and insulin deficiency in such infected animals is the result of lysis of the insulin-producing B cells. Lysis of B cells and the resulting hypoinsulinaemia and hyperglycaemia may be accompanied by mononuclear cell infiltration in and around the islets of Langerhans $[3,6]$.

While EMC-M virus may persist in the islets of Langerhans from infected mice for up to 3 weeks, ab-

\footnotetext{
* Present address: Centre for Clinical Immunology, The University of Sydney, NSW 2006, Australia
}

normal glucose tolerance curves can be detected in the mice for up to 1 year, even in the absence of ultrastructural changes in the islets of Langerhans [7]. To explain this finding it has been suggested that EMC-M virus infection in mice may trigger immunologically mediated islet cell damage [8] or alternatively that there is a persistent infection of the B. cells.

In short term experiments, an almost complete inhibition of insulin biosynthesis was reported in microdissected islets of Langerhans from mice inoculated with EMC virus 60-70 $\mathrm{h}$ after infection [9].

In addition, in a tissue culture of mouse islets infected with EMC virus in vitro, significant depression of insulin biosynthesis and release was evident within a few days [10]. However, biochemical changes in islets, from animals inoculated with EMC virus some months earlier, have not so far been investigated.

In these experiments we were particularly anxious to investigate whether minimal disturbances in carbohydrate metabolism following infection could persist or be accompanied by metabolic changes within the islets. 


\section{Materials and methods}

Male, 8-10-week-old, DBA/2 mice (Blackburn Animal House, Department of Immunology, University of Sydney, NSW, Australia) were housed in individual cages or in groups of six in a 12-h light-dark cycle and provided with water and 'Rat and Mouse Kubes' ad libitum. (Allied Feeds, Rhodes, NSW, Australia). Mice were inoculated intraperitoneally with $0.2 \mathrm{ml}$ of a suspension of the $\mathrm{M}$ strain of encephalomyocarditis virus (EMC-M variant) [11] containing $400 \mathrm{I} \mathrm{D}_{50}$ (infective dose) of virus for suckling mice. Control mice were injected in the same manner with a normal mouse heart suspension at the same dilution as the EMC-M virus.

The myocardial (M) strain of EMC virus was kindly donated by Dr D. R. Gamble, Public Health Laboratory, West Park Hospital, Epsom, UK, and for certain experiments by Professor J.E.Craighead, Department of Pathology, University of Vermont College of Medicine, Burlington, Vermont, USA.

\section{Passage of virus}

The virus derived from Epsom was passaged five times into cells and then once in mouse hearts. That derived from the United States was given two passages in mouse embryo fibroblasts.

\section{Experimental design}

Infected mice were selected for study if their individual blood glucose levels were more than 2 SD above the control range for at least 5 consecutive days. The selected mice were killed by cervical dislocation 60 days after inoculation and the pancreas immediately removed. At this time random blood glucose levels had returned to normal. Chronically hyperglycaemic mice were not used.

\section{Glucose estimations}

Early morning blood glucose levels of fed infected and control mice were determined in blood samples taken from the tail; insulin levels were measured in samples from the axillary artery. Glucose was estimated in these samples by the glucose oxidase/horseradish peroxidase system commercially available from Boehringer, Lewes, Sussex, UK. Serum insulin and insulin secreted into the medium were assayed by radioimmunoassay [12]. Insulin antiserum and human insulin standards were supplied by Wellcome, Beckenham, Kent, UK. In our hands, the assay curves for the lower and most useful range of insulin values did not exhibit differences when human insulin standards were compared with standards made from authentic rodent insulin.

\section{Pancreatic insulin content}

Pancreases were obtained from five control and five infected mice; they were pooled, and total insulin determined by a standard acid/ ethanol procedure (ethanol $75 \mathrm{ml}$, water $25 \mathrm{ml}, 12 \mathrm{~mol} / 1 \mathrm{HCl} 1.5 \mathrm{ml}$ ). After extraction and centrifugation, the supernatants were removed and the pellets re-extracted with acid/ethanol. The samples were then diluted with a $0.05 \mathrm{~mol} / 1$ phosphate buffer ( $\mathrm{pH} 7.4$ ) for immunoassay.

\section{Insulin secretion}

Pancreases from infected and control mice were removed and immediately placed in a buffered bicarbonate medium [13]. The pancreases were trimmed of fat and connective tissue, distended with the buffer and cut into small pieces before digestion with collagenase [14]. Groups of five islets were transferred to flat bottomed plastic tubes and pre-incubated in $2 \mathrm{ml}$ of freshly gassed $\left(5 \% \mathrm{CO}_{2} / 95 \% \mathrm{O}_{2}\right)$ medium [13] containing glucose $(2 \mathrm{mmol} / 1)$ for $30 \mathrm{~min}$ at $37^{\circ} \mathrm{C}$ in a shaking water bath. After this period, the supernatant was removed and replaced with $2 \mathrm{ml}$ of incubation medium containing glucose $(2,10$ or
$16 \mathrm{mmol} / 1)$. The islets of Langerhans were then incubated at $37^{\circ} \mathrm{C}$ in a shaking water bath for a further $1 \mathrm{~h}$, after which the supernatants were removed and stored at $-20^{\circ} \mathrm{C}$ pending insulin assay.

\section{Insulin biosynthesis}

To determine the rate of insulin biosynthesis, groups of 30 islets were first pre-incubated in $150 \mu \mathrm{l}$ gassed buffer [13] containing glucose $(2 \mathrm{mmol} / 1)$ for $30 \mathrm{~min}$ at $37^{\circ} \mathrm{C}$ in a shaking water bath. The buffer was then removed and replaced with $200 \mu 1$ of the bicarbonate medium containing $0.1 \mathrm{mCi}$ of $L\left(4,5^{3} \mathrm{H}\right)$-leucine and glucose concentrations of 2,10 and $16 \mathrm{mmol} / 1$, respectively [15]. After 1 -h incubation, the medium was aspirated and the islets washed three times with bicarbonate buffered medium. $\mathrm{HCl}(0.01 \mathrm{~mol} / \mathrm{l}, 100 \mu \mathrm{l})$ was added to the washed islets and they were sonicated at 25 watts for $12 \mathrm{~s}$ with a Branson Sonifier (Model B15P, Dawe Instruments, London, UK). Radioactive insulin was isolated by the method of Berne [16]. No attempt was made to differentiate between insulin and proinsulin biosynthesis.

\section{Cyclic AMP estimation}

For determination of cyclic AMP accumulation in islets isolated from control and infected mice, 15 islets were pre-incubated for $30 \mathrm{~min}$ at $37^{\circ} \mathrm{C}$ in the buffered bicarbonate medium, containing glucose $(2 \mathrm{mmol} / 1)$. The vials were centrifuged, the medium removed and $15 \mu \mathrm{l}$ of fresh medium containing glucose $(2,20 \mathrm{mmol} / \mathrm{l})$ or glucose $(20 \mathrm{mmol} / \mathrm{l})+3$-isobutyl-1-methylxanthine (IBMX, $1 \mathrm{mmol} / \mathrm{l})$ added.

After incubation for $10 \mathrm{~min}$ at $37^{\circ} \mathrm{C}$ in a shaking water bath, the reactions were stopped by the addition of ice-cold $\mathrm{HCl}(0.1 \mathrm{mmol} / 1$, $35 \mu \mathrm{l})$ containing IBMX $(1 \mathrm{mmol} / \mathrm{l})$. The islets were sonicated and cyclic AMP was measured by radioimmunoassay using a commercial kit supplied by New England Nuclear Company, Boston, Mass, USA.

\section{Weight gain and food intake}

Control and infected mice were weighed on a toploading balance at daily intervals. Food consumed by the two groups of mice was weighed at weekly intervals.

\section{Statistical analysis}

Results are expressed as mean \pm SEM (with number of observations in parentheses). The significance of differences were assessed using Student's t-test. Values with $p<0.05$ were regarded as significant.

\section{Results}

Early morning blood glucose determinations were used to select mice for further experiments. Results for control mice and mice which received $400 \mathrm{I} \mathrm{D}_{50}$ EMC-M virus are shown in Figure 1. On days 7 and $8, \sim 30 \%$ of the infected mice showed blood glucose values $>2$ SD of the control mice. A few mice, however, exhibited frankly diabetic levels of blood glucose.

The rate of weight gain in control and infected mice was of the same order, apart from the first 7 days for infected mice. Nevertheless, at 60 days, infected mice weighed $1 \mathrm{~g}$ less than control mice $(27 \mathrm{~g})$. The mean food intake for control mice was $3.58 \mathrm{~g}$ of food per mouse per day. The infected group of mice consumed $9.5 \%$ less food ( $3.24 \mathrm{~g}$ of food per mouse per day) over the same period. 


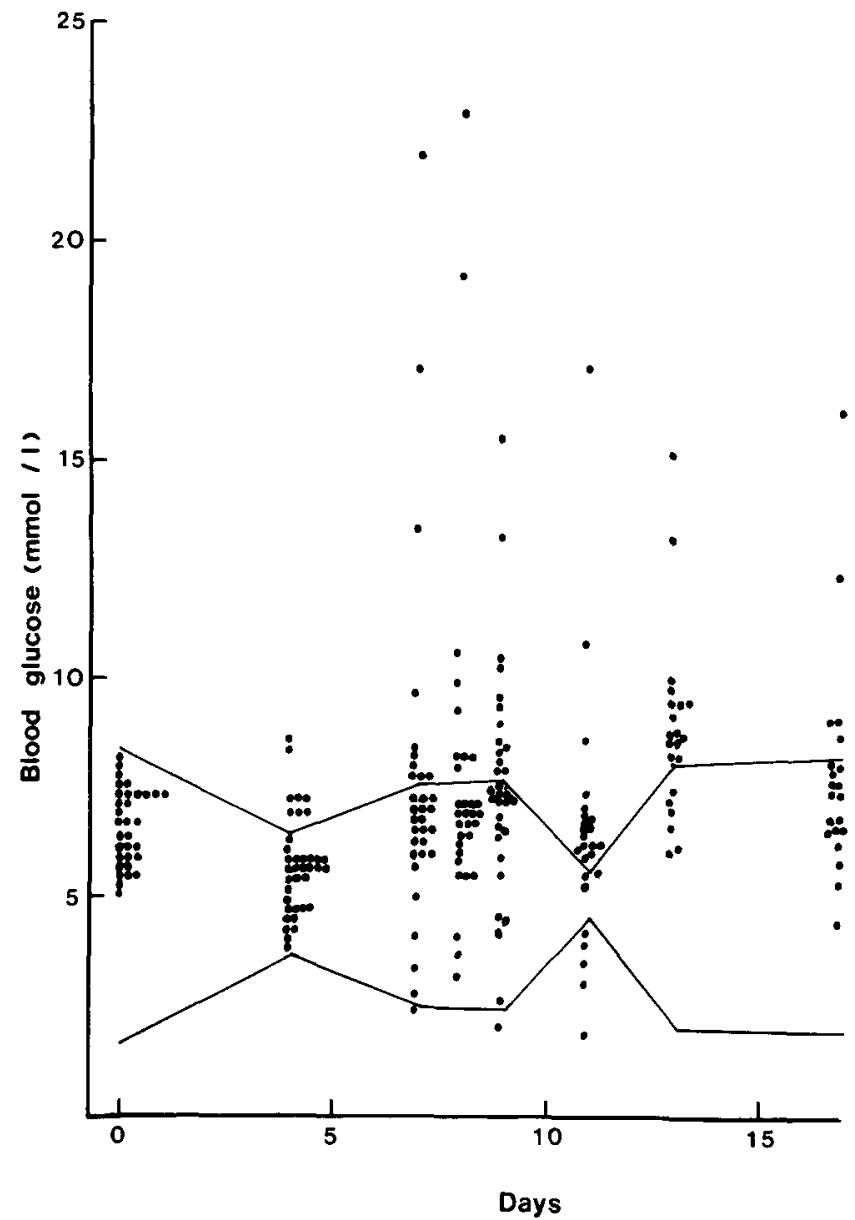

Fig. 1. Scatter of early morning blood glucose values for EMC infected mice. Control values fall between solid lines

The total pancreatic insulin content of infected mice was reduced to $39 \%$ that of control mice, 60 days after inoculation (Table 1). Although these observations are derived from a single pooled extract, the differences shown are very considerable. By contrast, the insulin content of isolated islets did not differ between the two groups. The inference is that although the total islet mass may be reduced, this is not caused by a lower insulin content per islet, but is due rather to a reduction in the number of islets, as the insulin content per islet from 'diabetic' mice was not different from that of control animals. Glucose and insulin levels in serum from control and infected mice are shown in Table 2. No statistically significant difference was found in the mean serum glucose levels from the two groups of mice. Serum insulin levels, however, showed a significant increase in infected mice $(p<0.002)$.

\section{Insulin secretion in isolated islets}

Insulin secretion rates in response to varying glucose concentrations in isolated islets of Langerhans obtained from control and infected mice 60 days after inoculation with EMC-M virus are shown in Table 3. At sub-
Table 1. Insulin content in the pancreas from control mice and mice inoculated with EMC-M virus, 60 days after infection

\begin{tabular}{lll}
\hline & \multicolumn{2}{l}{ Insulin content } \\
\cline { 2 - 3 } & ng/islet & U/g pancreas \\
\hline Control mice & $23.6 \pm 0.58(16)$ & 1.41 \\
Infected mice & $22.3 \pm 0.90(35)$ & 0.55 \\
\hline
\end{tabular}

Results are given as mean \pm SEM with number of observations in parentheses. For total islet insulin per pancreas, extracts from five pancreases were pooled and a single estimation was made on the combined extract

Table 2, Glucose and insulin levels in serum from control and infected mice

\begin{tabular}{lcr}
\hline & Control mice & Infected mice \\
\hline Serum glucose $(\mathrm{mmol} / \mathrm{l})$ & $9.7 \pm 0.6(11)$ & $9.8 \pm 0.7(30)$ \\
Serum insulin $(\mathrm{mU} / 1)$ & $30.8 \pm 3.4(11)$ & $45.2 \pm 3.0(20)^{\mathrm{a}}$ \\
\hline
\end{tabular}

Results are given as mean \pm SEM with number of observations in parentheses. ${ }^{a} p<0.002$, significant difference in serum insulin concentrations

Table 3. Insulin secretion from isolated islets of Langerhans from mice infected with EMC-M virus and from control mice 60 days after inoculation

\begin{tabular}{lll}
\hline $\begin{array}{l}\text { Glucose concentration } \\
(\mathrm{mmol} / \mathrm{l})\end{array}$ & \multicolumn{2}{l}{ Insulin secretion $\left(\mu \mathrm{U} \cdot \mathrm{min}^{-1} \cdot\right.$ islet $\left.^{-1}\right)$} \\
\cline { 2 - 3 } & Control mice & Infected mice \\
\hline 2 & $0.133 \pm 0.011(19)$ & $0.151 \pm 0.019(16)$ \\
10 & $0.211 \pm 0.017(16)$ & $0.292 \pm 0.021(17)^{\mathrm{a}}$ \\
16 & $0.734 \pm 0.048(16)$ & $0.518 \pm 0.035(15)^{\mathrm{b}}$ \\
\hline
\end{tabular}

Results are given as mean \pm SEM with number of observations in parentheses.

${ }^{\mathrm{a}} p<0.005$ and ${ }^{\mathrm{b}} p<0.0005$, significant differences between mean values in control and infected mice

Table 4. Insulin biosynthesis in islets of Langerhans isolated from control mice and mice infected with EMC-M virus

\begin{tabular}{|c|c|c|}
\hline \multirow[t]{2}{*}{$\begin{array}{l}\text { Glucose concentration } \\
(\mathrm{mmol} / \mathrm{l})\end{array}$} & \multicolumn{2}{|c|}{$\begin{array}{l}\text { Insulin biosynthesis (dpm }{ }^{3} \mathrm{H} \text {-leucine } \cdot \mathrm{ng} \\
\left.\text { insulin }{ }^{-1} \cdot \mathrm{h}^{-1}\right)\end{array}$} \\
\hline & Control mice & Infected mice \\
\hline 2 & $1.83 \pm 0.36(10)$ & $2.16 \pm 0.30 \quad(9)$ \\
\hline 10 & $10.00 \pm 1.00(10)$ & $9.55 \pm 0.80$ \\
\hline 16 & $17.90 \pm 2.20$ & $9.64 \pm 1.50(12)^{\mathrm{a}}$ \\
\hline
\end{tabular}

Results are given as mean \pm SEM with number of observations in parentheses. ${ }^{\text {a }} p<0.005$, significant difference between mean values in control and infected mice. $\mathrm{dpm}=$ disintegrations $/ \mathrm{min}$

stimulatory glucose $(2 \mathrm{mmol} / \mathrm{l})$, infected islets released more insulin than control islets, although the difference in mean values is not statistically significant. This apparent hypersecretion of insulin from islets of infected mice in response to glucose ( 2 and $10 \mathrm{mmol} / 1$ ) was reversed when the glucose concentration was increased to $16 \mathrm{mmol} / 1$. 

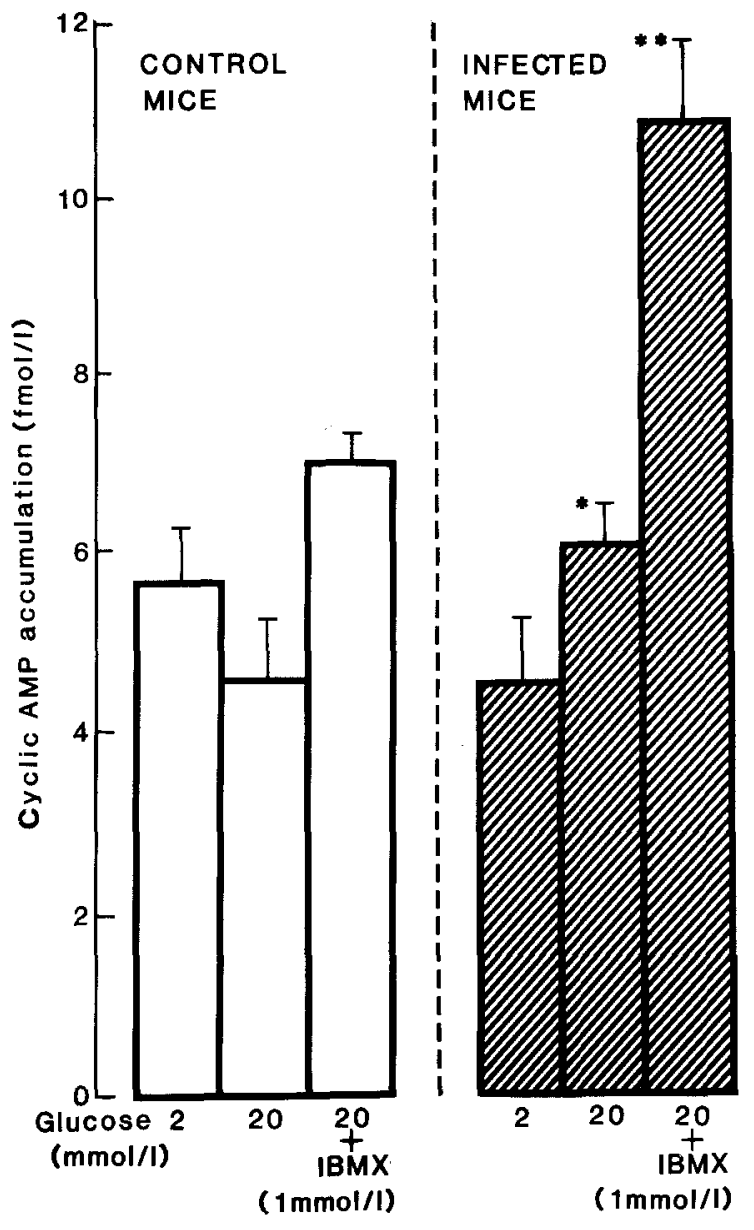

Fig. 2. Cyclic AMP accumulation in islets of Langerhans from mice previously inoculated with EMC virus and from control animals. Mice were inoculated with the $\mathrm{M}$ variant of $\mathrm{EMC}$ virus and the animals sacrificed after 60 days. Cyclic AMP was measured by an immunoassay procedure (see text). Results are expressed in terms of fmol cyclic AMP accumulation per litre buffer per islet per min (mean \pm SEM). At least six observations were made for each value. ${ }^{*} p<0.05$, and $* * p<0.001$, significant differences from corresponding control values

\section{Insulin biosynthesis}

The rates of insulin biosynthesis in response to glucose in islets of Langerhans isolated from control and infected mice are shown in Table 4. At glucose ( 2 and $10 \mathrm{mmol} / \mathrm{l}$ ) there was no difference in the rate of synthesis from islets in the two groups of mice. When control islets were exposed to glucose $(16 \mathrm{mmol} / \mathrm{l})$, the rate of insulin biosynthesis increased roughly twofold compared to that observed at glucose $(10 \mathrm{mmol} / \mathrm{l})$. Islets from diabetic mice, however, failed to show any increase in the rate of synthesis when glucose concentration was increased from 10 to $16 \mathrm{mmol} / \mathrm{l}$.

\section{Cyclic AMP accumulation}

There was an increased concentration of cyclic AMP in the islets of infected mice in the presence of glucose
(20 mmol/1) (Fig. 2). This was especially so after incubating the islets with glucose $(20 \mathrm{mmol} / \mathrm{l})$ plus IBMX.

\section{Ultrastructure of islets}

Both light and electron microscopy studies by conventional methods on the pancreas from control and infected mice revealed no obvious indication of the cellular dysfunction observed in the B cells from infected mice. The B cells from both groups of animals were well granulated, the endoplasmic reticulum, Golgi apparatus and mitochondria all appeared normal.

\section{Discussion}

As has been suggested by others, this study demonstrates that EMC-M virus infection in certain inbred strains of mice will induce a state of glucose intolerance. Zaheer et al. [17] reported that lower rates of insulin secretion were evident in response to glucose, 21 days after infection, using pancreases from EMC-M virus-infected mice. The mild diabetes shown in these mice may well be due to changes both in insulin secretion and biosynthesis. Data shown in this study suggest that these changes have persisted. Despite these biochemical changes in the infected islets, their insulin content did not differ from normal (Table 1). The lower insulin content of whole pancreas derived from infected animals may well reflect a reduced islet mass. It is also of interest that islets isolated from Coxsackie B4-infected mice showed a depressed insulin secretory response to high glucose concentrations 17 days after infection [3], as did hamsters infected with a strain of Venezuelan equine encephalitis virus [18].

The increased accumulation of cyclic AMP in the islets of infected mice also deserves comment. Increased concentrations of cyclic AMP were observed also in islet cells in tissue culture directly infected by EMC virus [10]. This effect now seem to have persisted over 60 days. In this instance too, an increase in cyclic AMP appears to be dissociated from the secretory activity of the cell.

Serum insulin levels in EMC-M virus-infected mice were elevated above those observed for control mice. In the presence of normal serum glucose levels this indicates some degree of peripheral insulin resistance. Perhaps the observed hypersecretion or 'leakage' of insulin seen in islets from such mice at glucose ( 2 and $10 \mathrm{mmol} / \mathrm{l}$ ) could lead to 'down regulation' of peripheral insulin receptors and as a result, a state of insulin resistance could develop.

Infected mice consumed slightly less food and weighed a little less than control mice and this factor could affect the secretory response of islets to glucose. Changes in dietary carbohydrate consumption are known to depress both the rate of bisoynthesis of insulin and its release [19] and these changes are apparent 
over a range of glucose concentrations. This appears not to be the case for the changes observed in islets from diabetic mice, since the rate of insulin biosynthesis is depressed only at high glucose concentrations $(16 \mathrm{mmol} / \mathrm{l})$ and is normal at 2 and $10 \mathrm{mmol} / 1$. Cyclic AMP concentrations, moreover, are increased in islets from infected animals after increased glucose. If a depressed food intake had affected islet function, cyclic AMP concentrations would be expected to be depressed [20]. A dietary change involving the consumption of less carbohydrate cannot therefore explain these results.

There are a number of other possible reasons for such long-term changes in islet function. Thus, immunological mechanisms may influence the development of diabetes in mice following infection with EMC-M virus $[21,8]$. It is also possible that longer term changes in the plasma membrane of the $B$ cells due to the virus may influence membrane permeability, as suggested by Carrasco [22]. These changes could indirectly alter insulin synthesis and secretion. Changes in $\mathrm{Ca}^{2+}$ fluxes (though not measured in these experiments), might be particularly important in this connection. Thus an increase of cytosolic $\mathrm{Ca}^{2+}$ might underlie the increased cyclic AMP concentrations shown to be present in infected cells, perhaps by affecting adenylate cyclase.

It will clearly be important to extend this work to longer periods of time after inoculation and to viruses other than EMC-M virus.

Acknowledgements. We wish to thank the British Diabetic Association and the Medical Research Council for grants which enabled this work to be carried out. We would also like to thank Dr. D. R. Gamble for his help, advice and encouragement throughout the work and in addition Mr. T. Ward for help with some of the assays.

\section{References}

1. Craighead JE, Steinke J (1971) Diabetes mellitus-like syndrome in mice infected with encephalomyocarditis virus. Am J Pathol 63: 119-130

2. Boucher DW, Notkins AL (1973) Virus induced diabetes mellitus. I. Hyperglycaemia and hypoinsulinaemia in mice infected with encephalomyocarditis virus. J Exp Med 137: 1226-1238

3. Coleman TJ, Gamble DR, Taylor KW (1973) Diabetes in mice after Coxsackie B4 virus infection. Br Med J 3:25-27

4. Yoon JW, Onodera T, Notkins AL (1978) Virus induced diabetes mellitus. XV. Beta cell damage and insulin-dependent hyperglycaemia in mice infected with Coxsackie virus B4. J Exp Med 148: 1068-1080

5. Toniolo A, Onodera T, Jordan G, Yoon JW, Notkins AL (1982) Virus induced diabetes mellitus. Glucose abnormalities produced in mice by the six members of the Coxsackie B virus group. Diabetes 31: 496-499
6. Craighead JE, Kanick RE, Kessler JB (1974) Lesions of the islets of Langerhans in encephalomyocarditis virus infected mice with diabetes mellitus-like syndrome. I. Acute lesions. Am J Pathol 74: 287-294

7. Wellman KF, Amsterdam D, Brooks SE, Volk BW (1975) Glucose tolerance and pancreatic ultrastructure in mice with long-term diabetes induced by EMC virus (M variant) (38518). Proc Soc Exp Biol Med 148: 261-262

8. Jansen FK, Muntefering H, Schmidt WAK, Beiner J (1977) Suggestion that immune reactions are needed for diabetes developing after EMC virus infection in the mouse. Diabetologia 13: 404-405

9. Petersen K-G, Heilmeyer P, Kerp L (1975) Synthesis of (pro)insulin and large glucagon immunoreactivity in isolated Langerhans islets from EMC virus infected mice. Diabetologia 11: 21-25

10. Hellqvist LNB, Taylor KW, Zaluzny S (1981) Selective disorganisation of $\mathrm{B}$ cells of the islets of Langerhans infected by EMC-M virus in tissue culture. FEBS Lett 132: 215-218

11. Craighead JE, McLane MF (1968) Diabetes mellitus: induction in mice by encephalomyocarditis virus. Science 162:913-914

12. Hales CN, Randle PJ (1963) Immunoassay of insulin with insulin antibody precipitate. Biochem. J 88: 137-146

13. Gey GO, Gey MK (1936) Maintenance of human normal cells and tumour cells in tissue culture. Am J Cancer 27: 45-76

14. Howell SL, Taylor KW (1968) Potassium ions and the secretion of insulin by islets of Langerhans incubated in vitro. Biochem $\mathrm{J} 108$ : $17-24$

15. Parry DG, Taylor KW (1974) Metabolites and the incorporation of L-leucine into rabbit insulin in vitro. Biochim Biophys Acta 353: 344-352

16. Berne C (1975) Anti-insulin serum coupled to Sepharose 4B as a tool for the investigation of insulin biosynthesis in the B cells of obese hyperglycemic mice. Endocrinology 97: 1241-1247

17. Zaheer F, Howell SL, Taylor KW, Gamble DR (1979) Pancreatic insulin and glucagon content and secretion after infection of mice with EMC virus. Diabetologia 17:51-57

18. Rayfield EJ, Seto Y, Walsh S, McEvoy RC (1981) Virus induced alterations in insulin release in hamster islets of Langerhans. J Clin Invest 68: 1172-1181

19. Bone AJ, Howell SL (1977) Alterations in regulation of insulin biosynthesis in pregnancy and starvation studied in isolated rat islets of Langerhans. Biochem J 166: 501-507

20. Howell SL, Green IC, Montague W (1973) A possible role of adenylate cyclase in the long term dietary regulation of insulin secretion from rat islets of Langerhans. Biochem. J 136: 343-349

21. Buschard K, Rygaard J, Lund E (1976) The inability of a diabetogenic virus to induce diabetes mellitus in athymic (nude) mice. Acta Pathol Microbiol Scand Sect C 84: 299-303

22. Carrasco L (1978) Membrane leakiness after viral infection and a new approach to the development of antiviral agents. Nature 272: 694-699

Received: 22 July 1983

and in revised form: 24 February 1984

Professor K. W. Taylor

Department of Biochemistry

The London Hospital Medical College

Turner Street

London E1 2AD, UK. 